OnLine Journal of Biological Sciences 12 (1): 21-26, 2012

ISSN 1608-4217

(C) 2012 Science Publications

\title{
Effect of Storing Temperature on Hepatotoxicity and Nephrotoxicity of Ifosfamide in Female Rat
}

\author{
Falah Mohammed Aziz \\ Department of Biology, College of Science, Salahaddin University, Erbil, Iraq
}

\begin{abstract}
Problem statement: Ifosfamide (IFO) is a cytotoxic alkylating drug used for the treatment of a variety of cancers, although it has been found to induce certain hematological, hepatotoxic and nephrotoxic side effects. This drug is widely used in developing country, especially Iraq, but without caring too much to the storing temperature due to low drug maintaining facilities. The present work was achieved to investigate the effect of different temperature degrees on the toxicity of IFO on liver and kidney of female rats. Approach: Ifosfamide $\left(60 \mathrm{mg} \mathrm{Kg}^{-1} \mathrm{~b}\right.$.wt) stored at different temperature degrees $\left(4,10\right.$ and $25^{\circ} \mathrm{C}$ ) was given to female rats to detect the effect of temperature degrees on hepatotoxicity and nephrotoxicity of this chemotherapeutic drug. A modified technique was used for demonstration the dying kidney cells. Results: All IFO treated rats showed Fanconi syndrome such as increase of serum creatinine, phosphorus, ALT and AST and decrease of glucose as well as an increase in serum Malondialdehyde (MDA) level. Ifosfamide was still maintained its antimitotic action in all the treated groups as revealed by examining the bone marrow smears. The biochemical estimation of ALT, AST and MDA showed significant temperature dependent increase in the toxicity of liver and kidney by this drug. The histopathological alteration in these two organs were come supportive to the above biochemical results. The liver of the rats exposed to IFO stored at $25^{\circ} \mathrm{C}$ showed higher liver steatosis, hemorrhage and more degeneration of hepatocytes. Similarly, more hemorrhage, degeneration of kidney tubule cells and lymphocytes infiltration in kidney were observed in the $25^{\circ} \mathrm{C}$ group in comparison to the other groups. A successful modified technique for staining thick plastic sections was employed revealing a specific color for the dying kidney cells. Conclusion: Although it can maintain its antimitotic property, IFO caused more severe hepatotoxic and nephrotoxic side effects if it is stored at temperature degree higher than $4^{\circ} \mathrm{C}$.
\end{abstract}

Key words: Ifosfamide, hepatotoxicity, nephrotoxicity

\section{INTRODUCTION}

Although Ifosfamide (IFO) is a highly effective chemotherapeutic agent for treatment of a variety of pediatric and adult solid tumors (Straka et al., 2003), it has been shown to induce many side effects such as hepatotoxicity (Paschke et al., 1988) and nephrotoxicity (Chen et al., 2008; Hanly et al., 2009). Nephrotoxicity may present in more severe cases as Fanconi syndrome (Skinner, 2003; Loebstein and Koren, 1998). The reactive toxic metabolite Chloroacetaldehyde (CAA), which is produced by the side-chain oxidation of IFO in renal tubular cells (Woodland et al., 2000), is believed to cause the nephrotoxic effect (Springate et al., 1999; Aleska et al., 2005) through inducing oxidative stress (Sener et al., 2004; Knouzy et al., 2010). Nissim et al. (2006) hypothesized that the CAA-induced dysfunction of mitochondrial oxidative phosphorylation in renal proximal tubules impairs energy production, thereby resulting in multiple metabolic abnormalities and cellular damage. Generally, drugs in developing countries may not always get perfect storing facilities, though facing many unfavorable conditions such as storing in high temperature degrees. Therefore, the aim of the present study was to investigate the effect of storing IFO at different temperature degrees on its toxic side effects in liver and kidney of female rats.

\section{MATERIALS AND METHODS}

Female albino rats were obtained from animal house of Biology Department, Science College, Salahaddin-University-Erbil. Twenty eight albino female rats (200-230 gm) were divided randomly into three groups ( 8 animals in each) and housed at $22 \pm 2{ }^{\circ} \mathrm{C}$ with $12 \mathrm{~h}$ light/dark cycle. They were supplied with standard laboratory animal care and fed rats diet and tap water ad libitum. The first group was the control and was given daily single intraperitoneal (i.p.) injection of one $\mathrm{mL}$ normal saline; the second group was given daily single (i.p.) of $1 \mathrm{~mL}$ Ifosfamide $\left(50 \mathrm{mg} \mathrm{kg}^{-1}\right.$.b.wt) (previously stored at $4^{\circ} \mathrm{C}$ ); the 3 rd group was given one 
$\mathrm{mL}$ of IFO previously stored at $10^{\circ} \mathrm{C}$, while the 4 th group was given daily i.p. injection of $1 \mathrm{~mL}$ Ifosfamide (previously stored in $25^{\circ} \mathrm{C}$ ) and all groups were sacrificed after six days. Storage of this drug in these degrees of temperature was for two weeks.

Blood collection: Blood samples were taken from the rats through cardiac puncture some into chilled tubes without EDTA for serum collection, centrifuged at $3000 \mathrm{rpm}$ for 15 minutes at $4^{\circ} \mathrm{C}$ and then the sera were stored at $-55^{\circ} \mathrm{C}$ for later biochemical analysis .

Determination of Serum Malondialdehyde (MDA): The level of serum MDA was determined spectrophotometrically by thiobarbituric acid (TBA) solution. In brief: $150 \mu \mathrm{L}$ serum sample was added to the followings: $1 \mathrm{~mL}$ Trichloroacetic Acid (TCA) 17.5\%, $1 \mathrm{~mL}$ of $0.66 \%$ TBA, then mixed well by vortex, incubated in boiling water for $15 \mathrm{~min}$ and then allowed to cool. One $\mathrm{mL}$ of $70 \%$ TCA was added and left to stand at room temperature for $20 \mathrm{~min}$, centrifuged at $2000 \mathrm{rpm}$ for $15 \mathrm{~min}$ and the supernatant was taken out for scanning spectrophotometrically (Weinstein et al., 2000).

Determination of serum creatinine: Colorimetric reaction of creatinine with alkaline picrate was measured kinetically at $490 \mathrm{~nm}(490-510) \mathrm{nm}$. The kit was obtained from BIOLABO SA, Maizy, France.

Determination of serum phosphorous: In an acid medium, phosphate ions form a phosphomolydic complex with the ammonium molybdate. The absorbance measured at $340 \mathrm{~nm}$ is proportional to the concentration of phosphate ions in the specimen. The kit was obtained from BIOLABO SA, Maizy, France.

Determination of Serum Glucose: The absorbance was measured at $505 \mathrm{~nm}$. The kit was obtained from Plasmatic laboratory products LTD.

Determination of Serum alanine aminotransferase (ALT): The ALT was determined in serum and it relies on the following principle: the $\alpha$-Oxoglutarate reacts with L-Alanine in the presence of ALT to form LGlutamate plus Pyruvate. The kit was obtained from BIOLABO SA, Maizy, France. The absorbance was measured at $505 \mathrm{~nm}$.

Determination of serum aspartate aminotransferase (AST): The determination of serum AST is based on the principle that the $\alpha$-Oxoglutarate reacts with LAspartate in the presence of AST to form L-Glutamate plus Oxaloacetate. The kit was obtained from BIOLABO SA, Maizy, France. The absorbance measured at $505 \mathrm{~nm}$.
Bone marrow smear preparation: Another separate six groups of male rats (5 rats in each group) were used for this preparation. Rat femur was subcutaneously injected with colchicine (1.0 mg kg-1) $2 \mathrm{~h}$ before sacrifice. Bone marrow cells from control and experimental animals were processed for analysis of chromosomal aberrations by the method of Sharma and Sharma (1994). The bone marrow from the femurs was flushed into a centrifuge tube containing $0.9 \%$ saline and centrifuged at $500 \mathrm{~g}$ for $5 \mathrm{~min}$. The supernatant was removed and hypotonic $\mathrm{KCl}$ was added to the sediment. After incubation for $20 \mathrm{~min}$ at $37^{\circ} \mathrm{C}$, the contents were centrifuged for $5 \mathrm{~min}$ and the sediment was fixed in methanol-acetic acid(3:1v/v).Three changes of fixative were given prior to slide preparation. The slides were air-dried, stained in 5\% Giemsa solution and scored blindly. Bone marrow cells were examined for mitotic figures by scoring the number of cells in mitosis per 1000 bone marrow cells, then the percentage of mitotic cells were obtained.

Histological methods: Paraffin method: Liver and kidney were removed and fixed in Bouin $\square \mathrm{s}$ fluid, dehydrated, cleared and embedded in paraffin and cut into $4-5 \mu \mathrm{m}$ thick sections, then stained by hematoxylin and eosin (Murice-Lambert et al., 1989).

Plastic method: Tissue samples $\left(1 \mathrm{~mm}^{3}\right)$ were fixed in $2.5 \%$ glutaraldehyde in 0.1 Mcacodylate buffer $\mathrm{pH} 7.2-$ 7.4 for $24 \mathrm{~h}$, postfixed in $1 \%$ osmium tetroxide for $1 \mathrm{hr}$., dehydrated through a graded series of ethanol $(50,70,95$ and $100 \%$ ), cleared in propylene oxide and embedded in Araldite mixture. Plastic sections $(0.5-1 \mu \mathrm{m})$ were stained by $1 \%$ toluidine blue in $1 \%$ Borax for light microscopy) (Kiernan, 2008). Some of the latter stained sections were washed by slightly acidic water to obtain pink color for healthy epithelial cells in correspond to purple or blue color for dying cells and RBCs.

Statistical analysis: All data were expressed as means \pm standard error of mean $(\mathrm{M} \pm \mathrm{SE})$ and statistical analysis was carried out using statistically available software (SPSS version 11.5). One-way analysis of variance (ANOVA) was performed to test for significance followed by Duncan's multiple range comparison tests for comparisons between the groups. $\mathrm{P}$ values $\leq 0.05$ and 0.01 were considered significant.

\section{RESULTS}

The present investigation dealt with the study of the effect of the chemotherapic anticancer drug, Ifosfamide, stored at different temperatures degrees. It has been found that the toxicity of this drug, when given intraperitoneally, has been increased consequently after storing at 4,10 and $25^{\circ} \mathrm{C}$ in comparison to control and also to each other. 
OnLine J. Biol. Sci., 12 (1): 21-26, 2012

Table 1: Effect of IFO at different temperature degrees on some biochemical parameters

\begin{tabular}{lllllll} 
& MDA & Creatinine. & Phosph & Glucose. & AST & ALT \\
Groups & $\mu \mathrm{mol} / \mathrm{L}^{*}$ & $\mathrm{Mg} / \mathrm{dL} * *$ & $\mathrm{Mg} / \mathrm{dL}^{* *}$ & $\mathrm{Mg} / \mathrm{dL} \mathrm{L}^{* *}$ & IU/L** & IU/L* \\
\hline Control & $1.59 \pm 0.13^{\mathrm{a}}$ & $0.48 \pm 0.06^{\mathrm{a}}$ & $6.88 \pm 0.28^{\mathrm{a}}$ & $162.27 \pm 1.90^{\mathrm{c}}$ & $72.11 \pm 5.43^{\mathrm{a}}$ & $8.11 \pm 0.57^{\mathrm{a}}$ \\
$\mathrm{IF}\left(4^{\circ} \mathrm{C}\right)$ & $2.23 \pm 0.22^{\mathrm{b}}$ & $1.25 \pm 0.05^{\mathrm{b}}$ & $13.11 \pm 1.31^{\mathrm{b}}$ & $110.26 \pm 1.80^{\mathrm{b}}$ & $144.03 \pm 5.28^{\mathrm{b}}$ & $16.11 \pm 0.45^{\mathrm{b}}$ \\
$\mathrm{IF}\left(10^{\circ} \mathrm{C}\right)$ & $2.61 \pm 0.13^{\mathrm{b}}$ & $1.43 \pm 0.06^{\mathrm{b}}$ & $15.88 \pm 1.46^{\mathrm{b}}$ & $95.36 \pm 1.33^{\mathrm{b}}$ & $177.28 \pm 13.28^{\mathrm{c}}$ & $22.19 \pm 1.05^{\mathrm{c}}$ \\
$\mathrm{IF}\left(25^{\circ} \mathrm{C}\right)$ & $3.14 \pm 0.23^{\mathrm{c}}$ & $2.12 \pm 0.08^{\mathrm{bc}}$ & $18.33 \pm 1.92^{\mathrm{c}}$ & $77.26 \pm 0.42^{\mathrm{ab}}$ & $200.36 \pm 16.25^{\mathrm{d}}$ & $29.42 \pm 3.88^{\mathrm{d}}$ \\
\hline
\end{tabular}

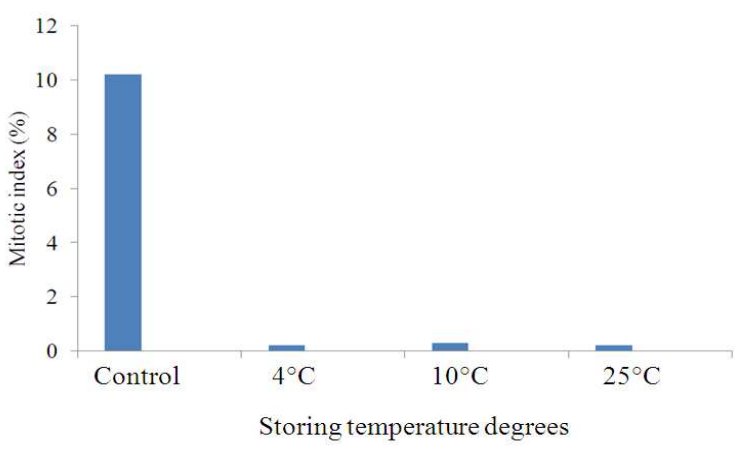

Fig. 1: Mitotic indices in the bone marrow of studied groups

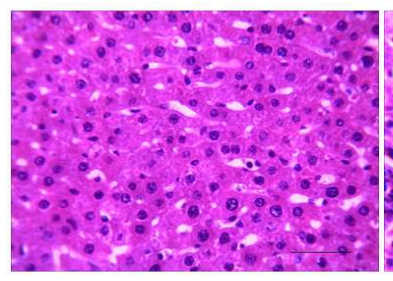

(a)

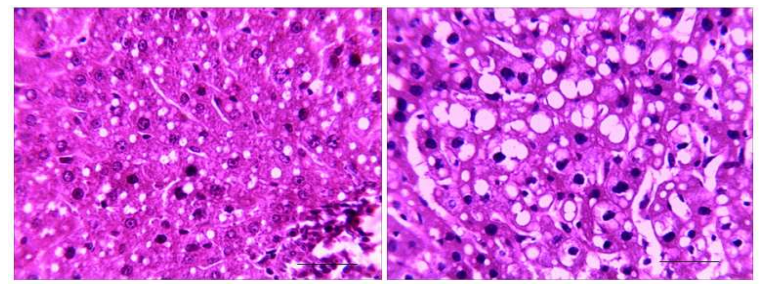

(c)

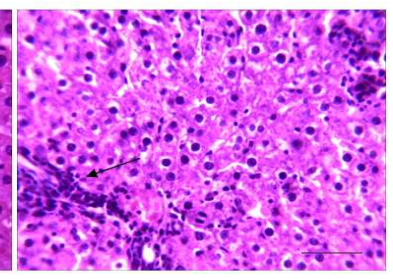

(b)

(d)
Fig. 2: Liver sections in: (a) control showing normal histological structure, (b) IFO (stored at $4^{\circ} \mathrm{C}$ ) treated rats showing pyknotic nuclei and appearance of some inflammatory leucocytes infiltration (arrow), (c) IFO (stored at $10^{\circ} \mathrm{C}$ ) treated rats showing pyknotic nuclei and fatty degeneration, (f) IFO (stored at $25^{\circ} \mathrm{C}$ ) treated rats showing pyknotic nuclei and appearance of larger size and higher number of lipid droplets, All are $\mathrm{H}$ and E. bar $=25 \mu \mathrm{m}$

As shown in Table 1, IFO showed significant increasing of serum MDA, AST, ALT, phosphorus and creatinine levels and decreasing of glucose level according to increase in storing temperature degrees, reporting higher change at $25^{\circ} \mathrm{C}$.

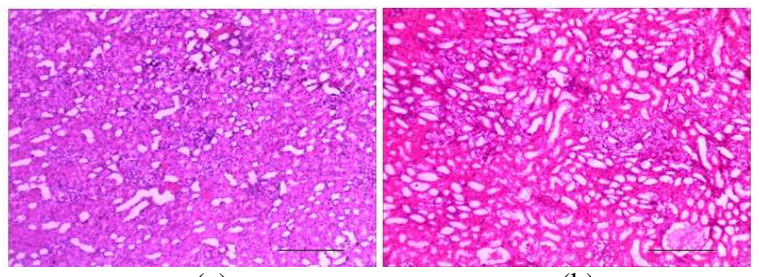

(a)

(b)

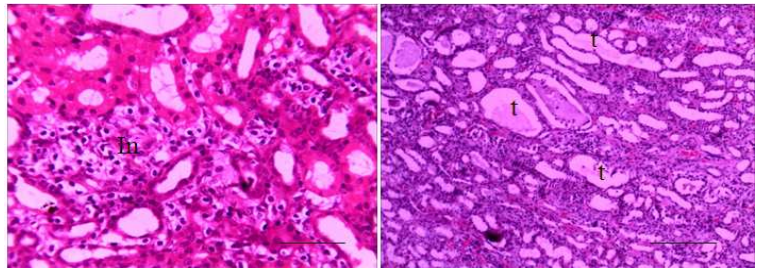

(c)

(d)

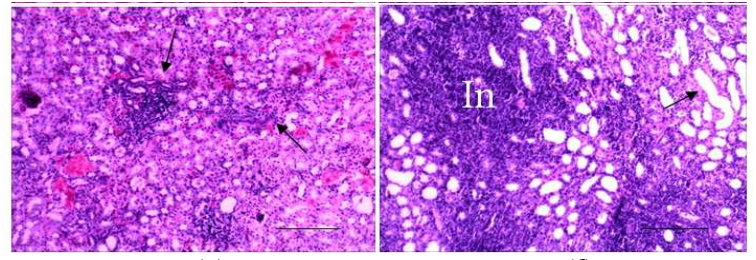

(e)

(f)

Fig. 3: Kidney sections in: (a) control group showing normal histological structure, (b-d) IFO (stored at $4^{\circ} \mathrm{C}$ ) showing kidney tubule dilatation ( $\mathrm{t}$ ), inflammation foci (In) and hemorrhage, (e) IFO (stored at $10^{\circ} \mathrm{C}$ ) caused high inflammation density (arrows) and hemorrhage, (f) IFO (stored at $25^{\circ} \mathrm{C}$ ) showing highly inflammated regions (In) and more dilatation of kidney tubule lumens (arrow). Bar in a, b, e and $\mathrm{f}=$ $100 \mu \mathrm{m}$, bar in $\mathrm{c}$ and $\mathrm{d}=25 \mu \mathrm{m}$

All IFO treated groups showed arrested mitosis in which approximately no mitotic division was detected in the bone marrow in comparison to the normal mitosis in control group in which $10.30 \%$ mitotic index was recorded (Fig. 1). In liver, IFO stored at $4{ }^{\circ} \mathrm{C}$ caused degeneration of hepatocytes, pyknosis of the nuclei, appearance of inflammatory leucocytes (Fig. 2b), while after exposing the rats to IFO stored at $10^{\circ} \mathrm{C}$, liver steatosis was evident (Fig. 2c). The liver of the rats exposed to IFO stored at $25^{\circ} \mathrm{C}$ showed higher quantity of liver steatosis. In the latter group, dilatation in the lumen of blood sinusoid was also observed (Fig. 2d). 


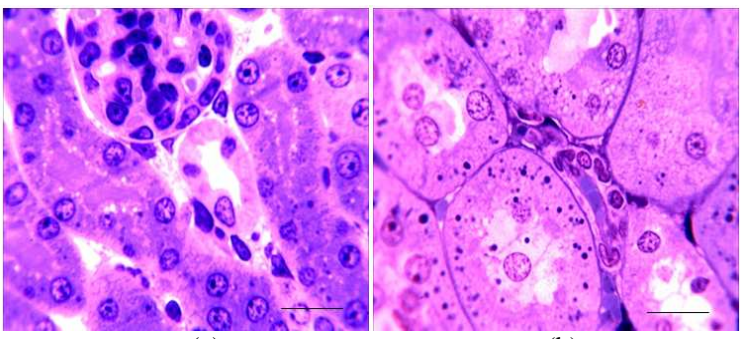

(a)

(b)

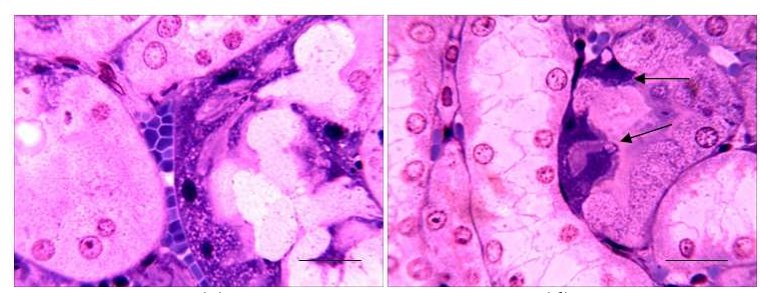

(c)

(d)

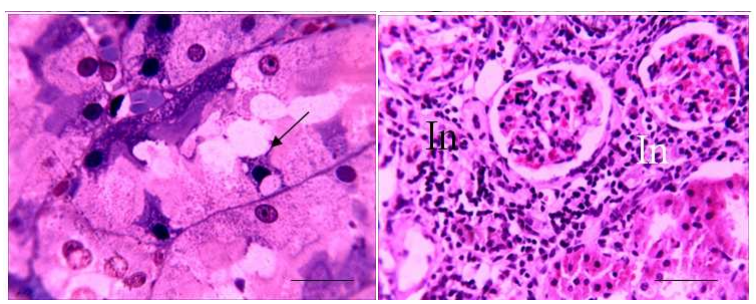

(e)

(f)

Fig. 4: Plastic sections in rat kidney in: (a) and (b) control group showing healthy kidney tubule lining cells, (c) IFO (stored at $4^{\circ} \mathrm{C}$ ) treated rat kidney showing few dying cells with highly vacuolated purple cytoplasm and dark condensed nuclei, notice the pink healthy cells. (d) high density of dying cells (arrows) in the $10^{\circ} \mathrm{C}$ stored IFO, (e) Higher density of dead or dying cells the IFO (stored at $25^{\circ} \mathrm{C}$ ) treated group, notice the shrunken dying epithelial cell having a large lipid droplet (arrow), (f) highly inflammatory region (In) around two glomeruli in the $25^{\circ} \mathrm{C}$ stored IFO group. Bars in all figures $=10 \mu \mathrm{m}$ except $\mathrm{f}$ which is equal to $25 \mu \mathrm{m}$

Regarding the kidney, this nephrotoxic drug caused dilatation in kidney tubules, hemorrhage and inflammation (Fig. 3b-d) in the kidney of rats exposed to IFO stored at $4^{\circ} \mathrm{C}$. These alterations were also existed in the 10 and $25^{\circ} \mathrm{C}$ storing condition, but the inflammatory areas were higher at $10^{\circ} \mathrm{C}$ (Fig. 3e) and more higher at $25 \mathrm{C}$ (Fig. 3f). As shown in Fig. 4, the density of dead proximal and distal convoluted tubule cells (PCT and DCT respectively) appeared increased according to increased storing temperature degrees. The dying cells appeared shrinked, highly vacuolated and contained condensed nuclei. These dying or dead cells appeared more clear with their purple cytoplasm and dark condensed nuclei in correspond to pink cytoplasm and nuclei of healthy cells as revealed by the modified method used in the present work. Following this technique, high inflammation was seen around glomeruli in the kidney of $25^{\circ} \mathrm{C}$ group (Fig. 4f).

\section{DISCUSSION}

As shown in the present, the level of serum MDA in the IFO treated rats were significantly higher than those of the control group. Similar finding was detected in serum of male rats (Chen et al., 2008; Asaad and Aziz, 2012). An elevation in serum MDA level is parallel to the increase of lipid peroxidation rate (Esterbauer et al., 1991). At the same time, elevation in lipid peroxide level indicates the presence of oxidative tissue damage as a result of impaired antioxidant defense mechanism (Sehirli et al., 2007) and this oxidative stress may cause the death of cells, especially the apoptotic cell death mode (Ramaekers et al., 1997).

Elevation of the two liver enzymes ALT and AST in the serum of IF treated rats refers to the hepatic cellular injury (Green and Flamm, 2002; Clark et al., 2003) because damaged liver cells develop leaky membranes, allowing for escape of intracellular enzymes (including ALT, AST and other enzymes) into the blood stream and this will raise the levels of these enzymes in the serum (Amacher, 1998). Elevation of ALT may be also due to liver steatosis (Shi et al., 2008) as noted in the present study.

The degeneration of hepatocytes which has been detected in the IFO treated rats may be related to the toxic metabolites of IFO and especially CAA, which may induce cell death through the depletion of hepatocellular GSH, ATP and enhanced lipid peroxidation rate (Sood and O'Brien, 1994), although the pathophysiology of this toxicity is not fully understood (Knouzy et al., 2010). It has been found that CAA collapsed the mitochondrial membrane, induced the release of cytochrome $\mathrm{C}$ from mitochondria to the cytosol and significantly reduced cellular ATP level that triggers cell death. The mechanism of such cell death follows the apoptotic cell death (Takahashi et al., 2007), although necrotic mechanism of cell death has also been mentioned by other workers (Daniel et al., 1992). Infiltration of inflammatory leucocytes which already use to accompany necrosis (Schwerdt et al., 2007; Chen et al., 2008) was seen in the present study. The fatty changes or liver steatosis caused by using IFO stored at 10 and $25^{\circ} \mathrm{C}$ may be related to changes in the chemical structure of the drug due to storing temperature. This fatty change is an abnormal phenomenon related to many xenobiotics (Klaassen, 2001). 
The death of PCT cells in the IFO treated rats are mainly due to the toxic effects of IFO metabolites, acroline and CAA and not by ifosfamide itself, as suggested by other investigators (Schwerdt et al., 2006). Regarding the mechanisms of (IFO)-induced nephrotoxicity, several hypotheses have been put forward, among which oxidative stress and depletion of Glutathione (GSH) were suggested (Chen et al., 2008; Aleska et al., 2005).

In accordance with the present results, it was previously shown that IFO caused severe renal damage in rats as indicated by the distorted proximal tubules with sloughing cells, sever interstitial inflammation and degenerated glomeruli (Sehirli et al., 2007; Chen et al., 2008; Asaad and Aziz, 2012).

Disappearing of mitotic figures in IFO treated group in comparison to normal existence of mitotic division in control may refer to maintaining of certain chemical compound constituents after using different storing temperature degrees. These chemicals seems to still have the antimitotic power, a characteristic property of the anticancer drugs including IFO.

As far as our literature survey could ascertain, no attempt was made to study the hepatotoxicity or nephrotoxicity of IFO stored at different temperature degrees. Most investigations done in this field used IFO stored at refrigerator, i.e., approximately $4^{\circ} \mathrm{C}$. The present investigation suggests that at higher temperature, i.e., above $4^{\circ} \mathrm{C}$, the chemical structure of this drug may undergo chemical changes yielding more toxic compounds. For this reason, the current results recommend to use IFO stored only at $4{ }^{\circ} \mathrm{C}$. This may guarantee minimum hepatotoxic and nephrotoxic side effects caused by IFO, since chemotherapy-related deaths due to their side effects, especially nephrotoxicity, still occur.

\section{CONCLUSION}

The present investigation showed that leaving ifosfamide in temperature degree higher than $4 \mathrm{C}^{\circ}$ caused higher degree of hepatic and nephrotic histological and physiological side effects, although it is still retained its antimitotic action.

\section{REFERENCES}

Aleska, K., N. Halachmi, S. Ito and G. Koren, 2005. A tubule cell model for ifosfamide nephrotoxicity. Can. J. Physiol. Pharmacol., 83: 499-508.

Amacher, D.E., 1998. Serum Transaminase Elevations as Indicators of Hepatic Injury Following the Administration of Drugs. Regul. Toxicol. Pharmacol., 27: 119-30. DOI: 10.1006/rtph.1998.1201
Asaad, H.R. and F.M. Aziz, 2012. Protective role of omega-3 fish oil against the toxicity of ifosfamide in male rats. Jord. J. Biol. Sci., 5: 37-46.

Chen, N., K. Aleksa, C. Woodland, M. Rieder and G. Koren, 2008. The effect of $\mathrm{N}$-acetylcysteine on ifosfamide-inducednephrotoxicity: in vitro studies in renal tubular cells. Translational Res., 150: 5157. DOI: $10.1016 /$ j.trsl.2007.02.001

Clark, J.M., F.L. Brancati and A.M. Diehl, 2003. The prevalence and etiology of elevatedaminotransferaselevels in the UnitedStates. Am. J. Gastroenterol., 98: 960-967. DOI: 10.1016/S0002-9270(03)00265-X

Daniel, F.B., A.B. DeAngelo, J.A. Stober, G.R. Olson and N.P. Page, 1992. Hepatocarcinogenicity of chloral hydrate, 2-chloro acet- aldehyde and dichloroacetic acid in male B6C3F1 mouse. Fundam. Appl. Toxicol., 19: 159-168. PMID: 1516771

Esterbauer, H., R.J. Schaur and H. Zollner, 1991. Chemistry and biochemistry of 4-hydroxynonenal, malonaldehyde and related aldehydes. Free Radic. Biol. Med., 11: 81-128. DOI: 10.1016/08915849(91)90192-6

Green, R.M. and S. Flamm, 2002. AGA Technical Review on the Evaluation of Liver Chemistry Tests. Gastroenterol., 123: 1367-1384. DOI: 10.1053/gast.2002.36061

Hanly, L., N. Chen, M. Rieder and G. Koren, 2009. Ifosfamide nephrotoxicity in children: a mechanistic base for pharmacological prevention. Expert Opinion Drug Safety, 8: 155-168. DOI: $10.1517 / 14740330902808169$

Kiernan, J.A., 2008. Histological and Histochemical Methods. 4th Edn., Cold Spring Harbor Laboratory, ISBN-10: 9781904842422 pp: 606.

Klaassen, C.D., 2001. Casarett and Doull's Toxicology. The Basic Science of Poisons. 6th Edn., McGrawHill Medical Publishing Division. New York.

Knouzy, B., L. Dubourg, G. Baverel and C. Michoudet, 2010. Targets of chloroacetaldehydeinducednephrotoxicity. Toxicol. In Vitro, 24: 99107. DOI: $10.1016 /$ j.tiv.2009.08.026

Loebstein, R. and G. Koren, 1998. Ifosfamide-induced nephrotoxicity in children: Critical review of predictive risk factors. Pediat., 101: E8-E12. DOI: 10.1542/peds.101.6.e8

Murice-Lambert, E., A. Banford and R. Folger, 1989. Histological preparation of implanted biomaterials for light microscopic evaluation of the implanttissue interaction. Biotech. Histoche., 64: 19-24.

Nissim, I., O. Horyn, Y. Daikhin, I. Nissim and B. Luhovyy et al., 2006. Ifosfamide-Induced Nephrotoxicity: Mechanism and Prevention. Cancer Res., 66: 7824-7831. DOI: 10.1158/00085472.CAN-06-1043 
Paschke, R., P. Worst, J. Brust and W. Queisser, 1988. Hepatotoxicity with etoposide-ifosfamide combination therapy. Onkol, 11: 273-275. PMID: 2853857

Ramaekers, V.T., B. Bosman, G.A. Jansen and R.J.A. Wanders, 1997. Increased plasma malondialdehyde associated with cerebellar structural defects. Arch. Dis. Child., 77: 231-234. DOI: 10.1136/adc.77.3.231

Schwerdt, G., A. Kirchhoff, R. Freudinger, B. Wollny and A. Benesic et al., 2007. Mensa or cysteine prevents chloroacetaldehyde-induced cell death of human proximal tubule cells. Pediatr. Nephrol., 22: 798-803. PMID: 17273862

Schwerdt, G., N. Gordjani, A. Benesic, R. Freudinger and B. Wollny et al., 2006. Chloroacetaldehydeand acrolein-induced death of human proximal tubule cells. Pediatr. Nephrol., 21: 60-67. DOI: 10.1007/s00467-005-2006-6

Sehirli, O., A. Sakarcan, A. Velioglu-Ogunc, S. Cetinel and N. Gedik et al., 2007. Resveratrol improves ifosfamide-induced Fanconi syndrome in rats. Toxicol. Appl. Pharmacol., 222: 33-41. DOI: 10.1016/j.taap.2007.03.025

Sener, G., O. Sehirli, B. Yegen, S. Cetinel and N. Gedik et al., 2004. Melatonin attenuates ifosfamideinduced Fanconi syndrome in rats. J. Pineal Res., 37: $17-25$. DOI: $10.1111 /$ j.1600079X.2004.00131.X

Sharma, A.K. and A. Sharma, 1994. Chromosome Techniques: A Manual. 1st Edn., Harwood Academic Publishers, USA, ISBN-10: 3718655136 pp: 368.

Shi, J.P., J.G. Fan, G.Q. Lou, L. Zhang and C.B. Hu et $a l, 2008$. Hepatic steatosis: A common reason for elevated alanine aminotransferase levels in HBsAg-positive chronic hepatitis B patients with low HBV DNA loads. Zhonghua Gan Zang Bing Za Zhi., 16: 818-22. PMID: 19032864
Skinner, R., 2003. Chronic ifosfamide nephrotoxicity in children. Med. Pediatr Oncol., 41: 190-197. DOI: 10.1002/mpo. 10336

Sood, C. and P.J. O'Brien, 1994. Chloroacetaldehydeinduced hepatocyte cytotoxicity: Mechanisms for cytoprotection. Biochemi. Phrmacol., 48: 1025-32. DOI: 10.1016/0006-2952(94)90374-3

Springate, J., K. Chan, H. Lu, S. Davies and M. Taub, 1999. Toxicity of ifosfamide and its metabolite chloroacetaldehyde in cultured renal tubule cells. In Vitro Cell Dev. Biol. Anim., 35: 314-317. DOI: 10.1007/s11626-999-0080-y

Straka, C., H. Hebart, S. Adler-Reichel, N. Werding and B. Emmerich et al., 2003. Blood stem cell collections after mobilization with combination chemotherapy containing ifosfamide followed by G-CSF in multiple myeloma. Oncol, 65: 94-98. DOI: $10.1159 / 000073368$

Takahashi, Y., D. Coppola, N. Matsushita, H. Cualing and M. Sun et al., 2007. Bif-1 interacts with Beclin 1 through UVRAG and regulates autophagy and tumorigenesis. Nat. Cell Biol., 9: 1142-1151. DOI: $10.1038 /$ ncb 1634

Weinstein, T., A. Chagnac, A. Korzets, M. Boaz and Y. Ori et al., 2000. Haemolysis in haemodialysis patients: evidence for impaired defence mechanisms against oxidative stress. Nephrol. Dial. Transplant., 15: 883-887. DOI: 10.1093/ndt/15.6.883

Woodland, C., S. Ito, C.P. Granvil, I.W. Wainer and J. Klein et al., 2000. Evidence of renalmetabolism of ifosfamide to nephrotoxicmetabolites. Life Sci., 68: 109-117. DOI: 10.1016/S0024-3205(00)00915-2 